\title{
Recenzja książki \\ o. prof. dra hab. Augustyna Jankowskiego OSB, Biblijna teologia czasu, Wydawnictwo Benedyktynów, Tyniec-Kraków 2018, ss. 71, wydanie 2
}

Zagadnienie czasu przewija się mniej lub bardziej wyraźnie przez liczne publikacje naukowe. Pojawia się bowiem w książkach i artykułach astronomów, geologów, biologów czy historyków. Warto wspomnieć, że astronomowie i geolodzy, publikując dane dotyczące wieku Kosmosu, w tym Ziemi, ujmują czas w miliardach lat. Z kolei biolodzy, przytaczając hipotetyczne terminy pojawiania się na ziemi różnych gatunków roślin i zwierząt, posługują się czasem mierzonym w milionach i tysiącach lat. W pracach zaś historyków pojawiają się daty podawane w tysiącach, setkach i dziesiątkach lat. Koniecznie należy podkreślić, że wszyscy wyżej wymienieni uczeni — bez względu na to, w jakich liczbach ujmują czas - zawsze rozumieją go wyłącznie w wymiarze chronologicznym. Pojmują go więc jedynie jako sumę upływających sekund, minut, dni, tygodni, miesięcy, lat, epok itd.

Jednak zagadnieniem czasu interesują się nie tylko wzmiankowani naukowcy. Zajmują się nim bowiem również teolodzy biblijni. Jednym z nich był o. prof. dr hab. Augustyn Jankowski OSB (1916-2005), Autor opiniowanej książki: Biblijna teologia czasu, która nakładem Wydawnictwa Benedyktynów ukazała się w Tyńcu i Krakowie w 2018 roku ${ }^{1}$.

Już z tytułu recenzowanej książki wynika, że jej Autor, zajmując się problemem czasu, czynił to nie tylko w wymiarze chronologicznym jak przyrodnicy i historycy, ale i w wymiarze historiozbawczym. Opisał więc czas nie tylko jako sumę upływających chwil, ale i jako dar Boży, jako moment właściwy na wykorzystywanie łask Bożych. Swoją zaś publikację podzielił na trzy części, które zatytułował: Wstęp - specyfika biblijnej koncepcji czasu (pierwsza część; ss. 7-18), Nowote-

\footnotetext{
${ }^{1}$ Pierwsze wydanie recenzowanej książki - 2001 rok.
} 
stamentowy eon eschatologiczny (druga część; ss. 19-40) oraz Dodatek, w którym poruszył zagadnienia związane ze znakami końca czasu (trzecia część; ss. 41-56). Warto jeszcze odnotować, że na początku książki umieścił Spis treści (ss. 5-6), a na jej końcu — liczne wykazy, a mianowicie: Wykaz skrótów (ss. 57-58), Bibliografię (ss. 59-62), Skorowidz biblijny (ss. 63-68), Skorowidz autorów (ss. 69-70), Skorowidz hebrajski (s. 71) oraz Skorowidz grecki (ss. 71-72).

$\mathrm{Z}$ trudem recenzuje się książkę tak nietuzinkowego naukowca, jakim był o. prof. dr hab. Augustyn Jankowski OSB. Był on bowiem genialnym teologiem biblijnym oraz wybitnym tłumaczem Biblii. Był wręcz ikoną polskiej biblistyki. Warto przypomnieć, że swego czasu należał do Papieskiej Komisji Biblijnej, że był wielokrotnie nagradzany między innymi doktoratem honoris causa Papieskiej Akademii Teologicznej w Krakowie i wreszcie, że spod jego pióra wyszły liczne publikacje, by wymienić tu tylko choćby takie jak: Królestwo Boże w przypowieściach, Biblijna teologia przymierza czy Duch Święty w Nowym Testamencie, należące już dziś do klasyki polskiej literatury biblijnej. Potrzeba więc i odwagi, i pokory, by podjąć się próby zrecenzowania publikacji o. prof. Jankowskiego pt. Biblijna teologia czasu, która właśnie się ukazała. Niniejsza recenzja zostanie zatem napisana w duchu ogromnego szacunku dla nieżyjącego już Mistrza. Poruszone zaś zostaną w niej zagadnienia literackie i merytoryczne.

Gdy chodzi o szatę literacką, to opiniowana książka została napisana językiem bardzo konkretnym, zwięzłym i obrazowym. Ale to nie dziwi. Jej bowiem Autor od zawsze słynął z doskonałego pióra. Od zawsze uważano go za pisarza, który w prostych słowach potrafi pisać o skomplikowanych zagadnieniach, który w obrazowy sposób umie przeprowadzać analizy filologiczne, filozoficzne i teologiczne, który jest w stanie dostrzec niuanse, zachodzące między synonimami różnych terminów teologicznych i tak je opisać, aby zrozumieli je nie tylko specjaliści z dziedziny biblistyki, ale i studenci teologii oraz zwykli miłośnicy Biblii. W tym miejscu niezbędnie należy uwypuklić, że w recenzowanej książce jej Autor przeprowadzał w bardzo czytelny i komunikatywny sposób analizy nie tylko polskich terminów teologicznych, ale i łacińskich, greckich oraz hebrajskich. Koniecznie należy również dodać, że terminy greckie i hebrajskie zawsze przytaczał w oryginalnym zapisie, podając równocześnie ich transliterację. W efekcie jego monogram stał się jeszcze bardziej czytelny, szczególnie dla osób, które nigdy nie miały kontaktu z językami biblijnymi.

Gdy zaś chodzi o zagadnienia merytoryczne, to analizowana publikacja została podzielona w jasny, logiczny i przejrzysty sposób. Jak już wspominano, książka składa się z trzech rozdziałów. I nieodzownie należy uwydatnić, że rozdziały te wyraźnie ze sobą korespondują, że każdy następny jest rozwinięciem poprzedniego i wreszcie, że w żadnym nie ma jakichkolwiek powtórzeń. Warto się im przyjrzeć. 
W pierwszej części swojej książki o. prof. Jankowski zaprezentował dwie koncepcje czasu, a mianowicie pogańską i judeochrześcijańską (ss. 7-18). Rekonstruując pogańską koncepcję czasu, oczywiście ukazał tę stworzoną przez Greków i Rzymian. Odnotował więc, że Grecy zaczęli rozumieć czas na sposób zamkniętego obwodu, koła od epoki Hezjoda (VII w. przed Chr.). Udowodnił, że dopiero pod jego wpływem zaczęli dostrzegać, że wszystko w życiu stale kręci się w kółko, że dzieje się tak zarówno w życiu pojedynczego człowieka i całych zbiorowości, jak i w przyrodzie. W życiu jednostki można wyróżnić regularnie następujące po sobie okresy: choroby i zdrowia, głodu i sytości, zmęczenia i wypoczynku, smutku i radości itd. W wypadku całych zbiorowości historia uczy, że pokolenia rodzą się i umierają. Na arenie zaś dziejów pojawiają się stale nowe mocarstwa, które najpierw wzrastają w siłę, po czym słabnąc, odchodzą w niebyt, ustępując miejsca nowym potęgom. Wreszcie reguła ta obowiązuje również $\mathrm{w}$ przyrodzie, ponieważ zmieniajace się pory roku następuja po sobie z regularną konsekwencją i to do tego stopnia regularną, że wydaje się, jakoby kręciły się po jakimś kole. Opisując zaś judeochrześcijańską koncepcję czasu, o. Jankowski podkreślił, że zdecydowanie różni się ona od koncepcji czasu Greków i Rzymian. Nie ma ona bowiem kształtu koła, lecz linii ciagłej. Udowodnił więc, że już Żydzi, a po nich chrześcijanie, rozumieli czas jako linię biegnącą od początku świata aż do dnia Sądu Ostatecznego wieńczącego dzieje ziemi. Wykazał zatem, że w koncepcji judeochrześcijańskiej — w przeciwieństwie do koncepcji pogańskiej — czas nie kręci się w kółko i nie zmierza donikąd, lecz biegnie ku Bogu.

Z kolei w drugiej części swojej książki o. prof. Jankowski przeanalizował za-

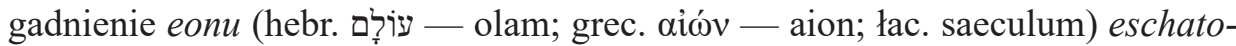
logicznego (ss. 19-40). Najpierw podkreślił, że istnieje ogromny zamęt, gdy chodzi o rozumienie tego określenia. Wyakcentował, że dość powszechnie zwykłym czytelnikom Biblii wydaje się, że eon eschatologiczny (= czasy ostateczne) to albo chwila ich własnej śmierci, albo bezpośredni moment poprzedzający Paruzję Jezusa. Dowiódł jednak, że to błędne myślenie. Wyjaśnił, że eon eschatologiczny to czasy, które rozpoczęły się wraz z pierwszym przyjściem Jezusa na świat. Wykazał również, że eon ten można podzielić na czasy Jezusa (od 7/6 r. przed Chr. do 30 r. po Chr.) i czasy Kościoła (od 30 r. po Chr. do końca świata). Podkreślił, że w pierwszym etapie tego eonu Jezus, przemierzając wioski, miasteczka i miasta Palestyny, osobiście namawiał przygodnie spotkanych ludzi do przemiany serca. Wygłaszał przy tym liczne przypowieści i czynił cuda. W drugim etapie tego eonu podobną rolę spełnia Kościół, kontynuujący dzieło swojego Mistrza. Czyni to zaś mocą Ducha Świętego i przy pomocy Sakramentów Świętych. I będzie to czynił aż do skończenia świata. Analizując eon eschatologiczny, o. Augustyn w sposób szczególny rozpatrzył dwa niezwykle ważne greckie terminy, a mianowicie: $\chi \rho o ́ v o \varsigma$ (chronos) i kaıрó (kairos). Najpierw rozświetlił znaczenie tego pierwszego i wykazał, że rzeczownik $\chi \rho o ́ v o \varsigma$ (chronos) oznacza 
czas będący sumą upływających chwil, godzin, dni, miesięcy, lat itd. Określa więc czas wyłącznie w wymiarze chronologicznym. Definiuje czas, który nawet utracony, i tak w jakiś sposób można odzyskać. Coś, czego bowiem nie udało się zdobyć wczoraj, będzie można zdobyć dziś lub jutro. Coś, czego nie udało się zrobić wczoraj, będzie można zrobić dziś bądź jutro. Następnie o. prof. Jankowski przeanalizował rzeczownik kaıрó (kairos) i uwydatnił, że oznacza on czas jako moment właściwy na wykorzystywanie darów i talentów Bożych, że określa czas w wymiarze historiozbawczym. Udowodnił przy tym, że czasu tego w żaden sposób nie można odzyskać. Raz bowiem zmarnowany, już nigdy więcej nie powróci. Niewykorzystane więc łaski Boże na pewno już nigdy nie wróca. Na koniec tej analizy Autor opiniowanej książki dodał jeszcze, że hebrajskimi odpowiednikami rzeczownika kaıрó (kairos) są cztery terminy, a mianowicie: עֵת (et), יעוֹ (jom). Wspomniał również, że aramejskimi ko-

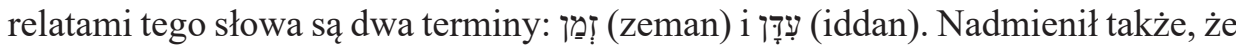
greckimi synonimami tego wyrazu bywają sporadycznie takie terminy jak: $\omega \rho \alpha$ $($ hora $=$ godzina $)$ oraz $v \tilde{v} v($ nyn $=$ teraz).

I wreszcie w trzeciej części recenzowanej publikacji o. Augustyn podjął próbę przeanalizowania znaków czasu. W tym celu przybliżył czytelnikom sens perykopy o znaku Jonasza (ss. 41-56). Najpierw oczywiście zacytował badany fragment, podkreślając, że jest to jedyny zapis kanoniczny, który zawiera określenie znaki czasu. Warto więc i w niniejszej recenzji go przytoczyć:

Przystąpili do Niego faryzeusze i saduceusze i wystawiając Go na próbę, prosili o ukazanie im znaku z nieba. Lecz On im odpowiedział: Wieczorem mówicie: Będzie piękna pogoda, bo niebo się czerwieni, rano zaś: Dziś burza, bo niebo się czerwieni i jest zasępione. Wygląd nieba umiecie rozpoznawać, a znaków cza-

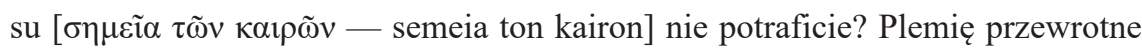
i wiarołomne żąda znaku, ale żaden znak nie będzie mu dany prócz znaku Jonasza. A zostawiwszy ich, odszedł [Mt 16,1-4; por. Mk 8,11-13; Łk 12,54-57].

Analizując ten zapis, o. prof. Jankowski uwydatnił, że we fragmencie tym

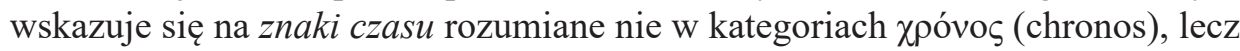
кaıрó (kairos). A zatem wykazał, że w perykopie tej nie ma instrukcji, jak na przykład obliczyć przybliżoną datę końca świata, lecz zachodzi w niej przestroga, by nie przeoczyć znaków poprzedzających chwalebne i ostateczne przyjście Jezusa na świat, jak faryzeusze i saduceusze przegapili moment Jego pierwszego przyjścia, by nie dać się zaskoczyć w dniu Paruzji, jak wrogowie Jezusa dali się zaskoczyć w dniu swojego nawiedzenia i nie rozpoznawszy Mesjasza, przypłacili to potępieniem wiecznym.

Niech te trzy syntetycznie zaprezentowane passusy recenzowanej książki będą potwierdzeniem tego, jak wielkiej wartości jest to publikacja. 
Nie pozostaje więc już nic innego, jak tylko polecić ją zarówno specjalistom, jak i niespecjalistom, biblistom i studentom teologii oraz zwykłym czytelnikom Biblii. Ubogaci ona bowiem warsztat naukowy tych pierwszych, a pogłębi wiedzę biblijną tych, którzy dopiero ją zdobywają, czy to systematycznie na uczelniach, czy też prywatnie podczas osobistej lektury. I nie trzeba chyba dodawać, że recenzowaną książkę czyta się z zapartym tchem, że z trudem odrywa się od niej wzrok. Nie trzeba chyba również przekonywać, że opiniowana publikacja o. prof. dra hab. Augustyna Jankowskiego OSB z pewnością już niedługo wejdzie - podobnie jak jego pozostałe książki - do kanonu polskiej literatury biblijnej. Warto więc już dziś ją przeczytać i mieć we własnej biblioteczce.

dr Jarosław Ćwikła ${ }^{2}$

Prymasowski Instytut Kultury Chrześcijańskiej w Bydgoszczy, Polska

\footnotetext{
2 Jarosław Ćwikła - doktor teologii biblijnej, wykładowca biblistyki, absolwent Prymasowskiego Instytutu Kultury Chrześcijańskiej w Bydgoszczy (1989-1994) oraz Podyplomowych Studiów Teologicznych na Wydziale Teologicznym Uniwersytetu im. Adama Mickiewicza w Poznaniu (1997-2001) i Podyplomowych Studiów Pedagogicznych dla Teologów także na WT UAM w Poznaniu (2004-2005). Od 2013 roku należy do Stowarzyszenia Biblistów Polskich; e-mail: drjaroslaw.cwikla@gmail.com. ORCID: 0000-0002-4325-1462.
} 